This document was prepared in conjunction with work accomplished under Contract No. DE-AC09-96SR18500 with the U. S. Department of Energy.

\title{
DISCLAIMER
}

This report was prepared as an account of work sponsored by an agency of the United States Government. Neither the United States Government nor any agency thereof, nor any of their employees, makes any warranty, express or implied, or assumes any legal liability or responsibility for the accuracy, completeness, or usefulness of any information, apparatus, product or process disclosed, or represents that its use would not infringe privately owned rights. Reference herein to any specific commercial product, process or service by trade name, trademark, manufacturer, or otherwise does not necessarily constitute or imply its endorsement, recommendation, or favoring by the United States Government or any agency thereof. The views and opinions of authors expressed herein do not necessarily state or reflect those of the United States Government or any agency thereof.

This report has been reproduced directly from the best available copy.

Available for sale to the public, in paper, from: U.S. Department of Commerce, National Technical Information Service, 5285 Port Royal Road, Springfield, VA 22161, phone: (800) 553-6847, fax: (703) 605-6900

email: orders@ntis.fedworld.gov

online ordering: http://www.ntis.gov/help/index.asp

Available electronically at http://www.osti.gov/bridge

Available for a processing fee to U.S. Department of Energy and its contractors, in paper, from: U.S. Department of Energy, Office of Scientific and Technical Information, P.O. Box 62, Oak Ridge, TN 37831-0062,

phone: (865)576-8401,

fax: (865)576-5728

email: $\underline{\text { reports@ adonis.osti.gov }}$ 
United States Department of Energy

Savannah River Site

\author{
Record of Decision
}

for the

Ford Building Waste Unit (643-11G)

Operable Unit (U)

WSRC-RP-98-4066

Revision 1

April 1999 


Printed in the United States of America
Prepared for
U. S. Department of Energy
and
Westinghouse Savannah River Company
Aiken, South Carolina




\section{RECORD OF DECISION \\ FOR THE FORD BUILDING WASTE UNIT (643-11G) \\ OPERABLE UNIT (U)}

WSRC-RP-98-4066

Revision 1

April 1999

Savannah River Site

Aiken, South Carolina

Prepared by:

Westinghouse Savannah River Company

For the

U. S. Department of Energy Under Contract DE-AC09-96SR 18500

Savannah River Operations Office

Aiken, South Carolina 
(This page intentionally left blank) 


\section{DECLARATION}

\section{Site Name and Location}

Ford Building Waste Unit (643-11G)

Savannah River Site

Aiken, South Carolina

The Ford Building Waste Unit (643-11G) (FBWU) Operable Unit is listed as a Resource Conservation and Recovery Act (RCRA) 3004(u) Solid Waste Management Unit/ Comprehensive Environmental Response, Compensation and Liability Act (CERCLA) unit in Appendix C of the Federal Facility Agreement (FFA) for the Savannah River Site (SRS).

\section{Statement of Basis and Purpose}

This decision document presents the selected remedial for the FBWU, in Aiken, South Carolina, which was chosen in accordance with CERCLA, as amended by SARA, and, to the extent practical, the National Oil and Hazardous Substances Pollution Contingency Plan (NCP). This decision is based on the Administrative Record File for this specific RCRA/CERCLA site.

The state of South Carolina concurs with the selected remedy.

Description of the Selected Remedy

The selected remedy for FBWU is "No Further Action". The Baseline Risk Assessment (BRA) considered current, future industrial and future residential land use scenarios. Based on these scenarios, the BRA concluded that there were no final constituents of concern (COCs) (i.e., no contaminant migration constituents of concern [CM COCs], human health COCs, or ecological COCs). Therefore, no further action is required to clean up the FBWU to acceptable levels.

\section{Declaration Statement}

A time-critical removal action was implemented in early 1997. This removal action focused 
on removing secondary sources consisting of surface and subsurface soils that contained levels of cesium- 137 above the time-critical action cleanup goal of $0.35 \mathrm{pCi} / \mathrm{g}$. The cleanup goal was set to the unit-specific two times $(2 \mathrm{X})$ average background.

Based on the FBWU RCRA Facility Investigation/Remedial Investigation (RFI/RI) Report and the BRA, no further action is necessary at the FBWU to ensure the protection of human health and the environment. Since the FBWU poses no risk to human health and the environment, and no further action is needed, the CERCLA Section 121 requirements are not applicable. The selected remedy is protective of human health and the environment, complies with federal and state requirements that are legally applicable or relevant and appropriate to the remedial action, and is meant to be a permanent solution, and final action, for the FBWU operable unit.

Section 300.430(f)(ii) of the National Oil and Hazardous Substances Pollution Contingency Plan requires that a Five-Year Review of the Record of Decision (ROD) be performed if hazardous substances, pollutants, or contaminants remain at the unit. The US EPA, SCDHEC, and US DOE have determined that a Five-Year Review of the ROD for the FBWU operable unit will not be performed. The remedial action for this unit ("No Further Action") results in no hazardous substances, pollutants, or contaminants remaining in the soils of the FBWU operable unit. 
Date

Thomas F. Heenan

Assistant Manager for Environmental Programs

U. S. Department of Energy, Savannah River Operations Office

Date

Richard D. Green

Division Director

Waste Management Division

U. S. Environmental Protection Agency - Region IV

Date

R. Lewis Shaw

Deputy Commissioner

Environmental Quality Control

South Carolina Department of Health and Environmental Control 


\title{
DECISION SUMMARY
}

FOR THE FORD BUILDING WASTE UNIT (643-11G)

OPERABLE UNIT (U)

\author{
WSRC-RP-98-4066 \\ Revision 1 \\ April 1999
}

\author{
Savannah River Site \\ Aiken, South Carolina
}

Prepared by:

Westinghouse Savannah River Company

For the

U. S. Department of Energy under Contract DE-AC09-96SR18500

Savannah River Operations Office

Aiken, South Carolina 


\section{TABLE OF CONTENTS}

Section

DECLARATION .1

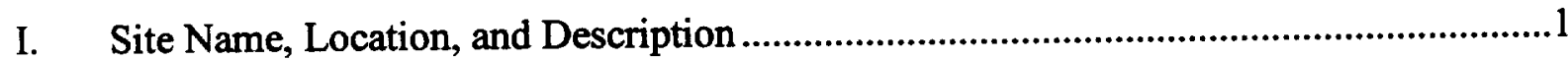

II. Site History and Enforcement Activities .....................................................................6

III. Highlights of Community Participation................................................................................

IV. Scope and Role of Operable Unit Within the Site Strategy ............................................11

V. Site Characteristics ...................................................................................................12

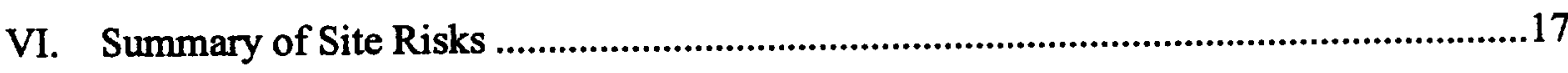

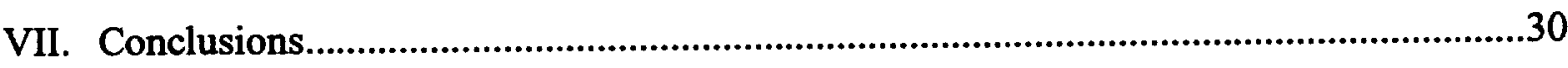

VIII. Explanation of Significant Changes .............................................................................32

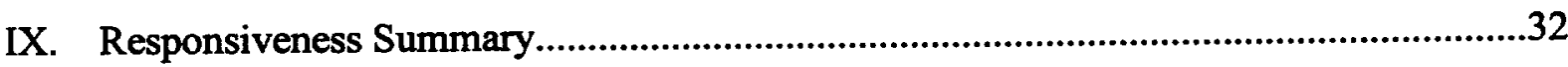

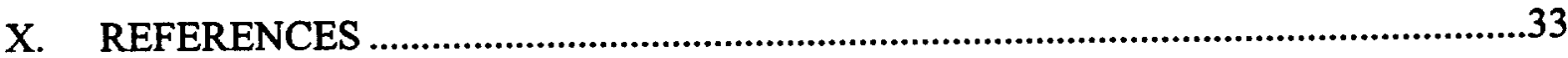

\section{LIST OF FIGURES}

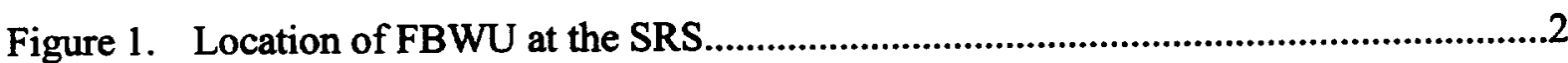

Figure 2. Oblique Aerial Photograph of the FBWU Area (April 1996)...................................3

Figure 3. Location of FBWU in the Fourmile Branch Watershed ...........................................4

Figure 4. Central Shops Enlarged Figure 3-3 from the FIP ....................................................

Figure 5. Excavation Map with Pre-Removal Sodium-Iodide Detector Survey Results .........7

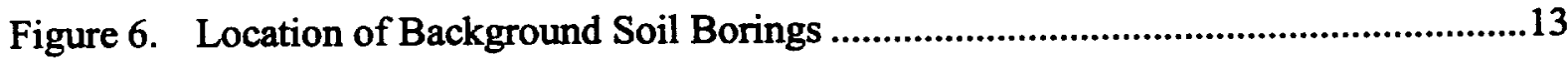

Figure 7. FBWU Sampling Locations............................................................................14

Figure 8. Conceptual Site Model for the FBWU...............................................................15

Figure 9. Summary of Chemical Risks and Hazards Across Pathways ................................19

Figure 10. Summary of Radiological Risks Across Pathways ................................................20 


\section{LIST OF TABLES}

Table 1. Risk Characterization Summary: Current Land Use Scenario - Surface Soil..........22

Table 2. Risk Characterization Summary: Future Land Use Scenarios - Surface Soil ..........23

Table 3. Risk Characterization Summary: Future Land Use Scenarios - Subsurface Soil ....24 


\section{ACRONYMS}

\begin{tabular}{|c|c|}
\hline $2 \mathrm{X}$ & two times \\
\hline ARARs & Applicable, or Relevant and Appropriate Requirements \\
\hline bls & below land surface \\
\hline BRA & Baseline Risk Assessment \\
\hline CERCLA & Comprehensive Environmental Response, Compensation and Liability Act \\
\hline CM COCs & Contaminant Migration Constituents of Concern \\
\hline COCs & Constituents of Concern \\
\hline COPCs & Constituents of Potential Concern \\
\hline ELCR & Excess Lifetime Cancer Risk \\
\hline FBWU & Ford Building Waste Unit (643-11G) \\
\hline FFA & Federal Facility Agreement \\
\hline FIP & FFA Implementation Plan \\
\hline $\mathrm{ft}$. & feet \\
\hline HI & Hazard Index \\
\hline HQ & Hazard Quotient \\
\hline $\mathrm{km}$ & Kilometer \\
\hline $\mathrm{m}$ & Meter \\
\hline mi. & Mile \\
\hline $\mathrm{pCi} / \mathrm{g}$ & Picocurie/gram \\
\hline RAOS & Remedial Action Objectives \\
\hline RBC & Risk Based Concentration \\
\hline RCRA & Resource Conservation and Recovery Act \\
\hline RFI & RCRA Facility Investigation \\
\hline RGOs & Remedial Goal Options \\
\hline RI & Remedial Investigation \\
\hline ROD & Record of Decision \\
\hline SCA & Soil Contamination Area \\
\hline SCDHEC & South Carolina Department of Health and Environmental Control \\
\hline SCHWMR & South Carolina Hazardous Waste Management Regulations \\
\hline sq. & Square \\
\hline SRS & Savannah River Site \\
\hline TCHI & Total Cumulative Hazard Index \\
\hline TCL & Target Compound List \\
\hline TCR & Total Cumulative Risk \\
\hline TICs & Tentatively Identified Compounds \\
\hline TMR & Total Medium Risk \\
\hline URMA & Underground Radioactive Materials Area \\
\hline USCs & Unit-Specific Constituents \\
\hline US DOE & U.S. Department of Energy \\
\hline US EPA & U.S. Environmental Protection Agency \\
\hline WSRC & Westinghouse Savannah River Company \\
\hline
\end{tabular}




\section{SITE NAME, LOCATION, AND DESCRIPTION}

Savannah River Site (SRS) occupies approximately 800 sq. km (310 sq. mi.) of land adjacent to the Savannah River, principally in Aiken and Barnwell counties of South Carolina. SRS is a secured U.S. Government facility with no permanent residents. SRS is located approximately $40 \mathrm{~km}$. (25 mi.) southeast of Augusta, Georgia, and 32 kilometers (20 miles) south of Aiken, South Carolina.

SRS is owned by the U.S. Department of Energy (US DOE). Management and operating services are provided by Westinghouse Savannah River Company (WSRC). SRS has historically produced tritium, plutonium, and other special nuclear materials for national defense.

The Ford Building Waste Unit (643-11G) (FBWU) is located near the center of the SRS (Figure 1). A photograph of the unit is provided as Figure 2. The FBWU now consists of a rectangular area measuring 9.1 to $10.4 \mathrm{~m}$ (30 to $34 \mathrm{ft}$ ) wide by $53.0 \mathrm{~m}$ (174 ft) long. Prior to a time-critical removal action in 1997, approximately one-half of the FBWU was marked with yellow chains and signs delineating an Underground Radioactive Materials Area (URMA). Additionally, the FBWU contained a Soil Contamination Area (SCA) of approximately $1 \times 1 \mathrm{~m}(3 \times 3 \mathrm{ft})$.

The FBWU is a source control and groundwater operable unit in the Fourmile Branch watershed (Figure 3). The Federal Facility Agreement (FFA) lists FBWU as a Resource Conservation and Recovery Act (RCRA)/Comprehensive Environmental Response, Compensation and Liability Act (CERCLA) unit, requiring evaluation using an investigation/assessment process that integrates and combines the RCRA Facility Investigation (RFI) process with the CERCLA Remedial Investigation (RI) to determine the actual or potential impact to human health and the environment.

The FBWU is located in the industrial buffer zone of N Area (Central Shops) and will remain industrial use in the future, in accordance with SRS Citizens Advisory Board Recommendation \#2. The unit is not located within an area expected for future Heavy Industrial (Nuclear Use) activity. Figure 4 (i.e., Figure 3-3 of FIP) is an enlarged section of the CAB Recommendation \#2 map. 


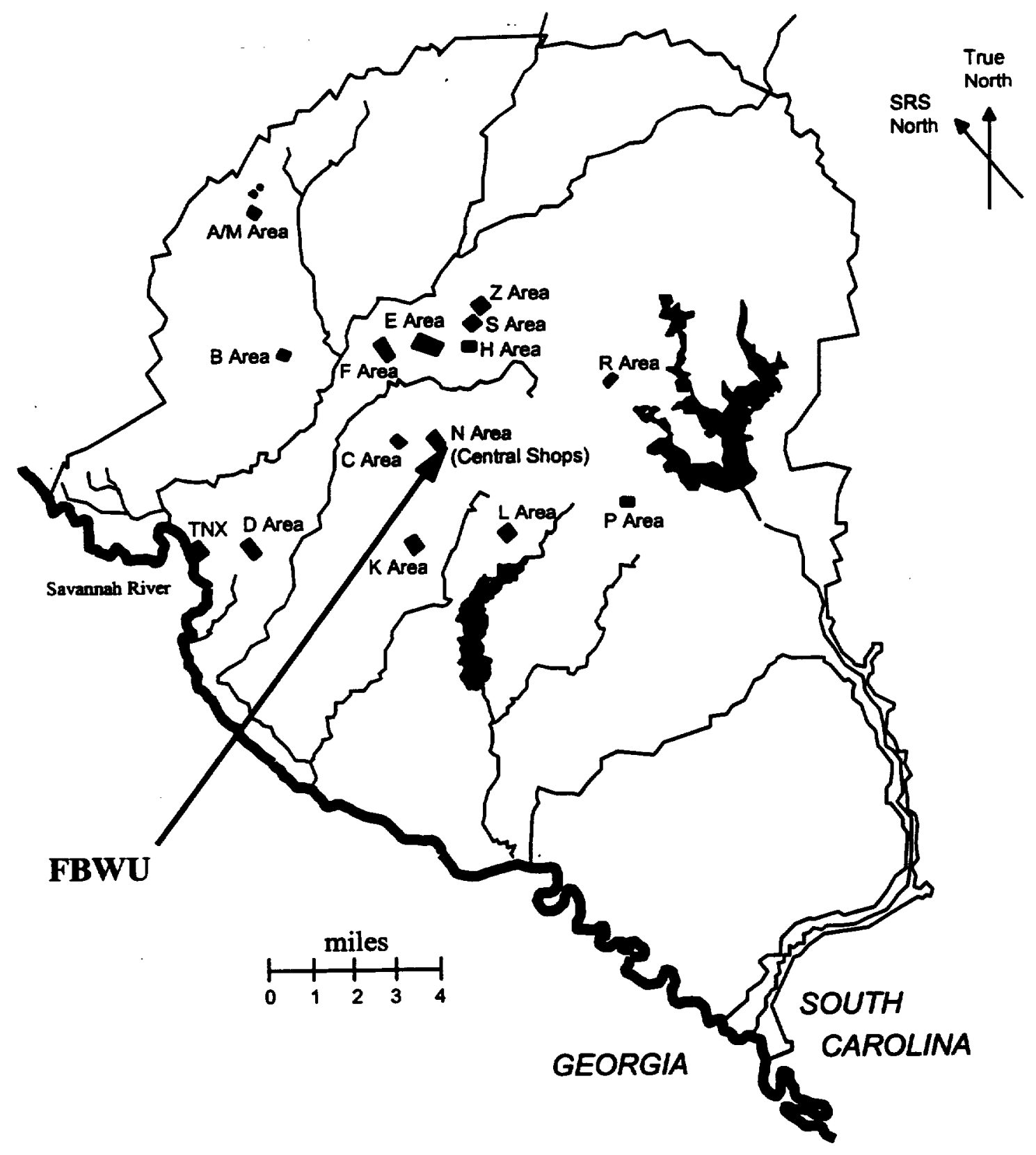

Figure 1. Location of FBWU at the SRS 


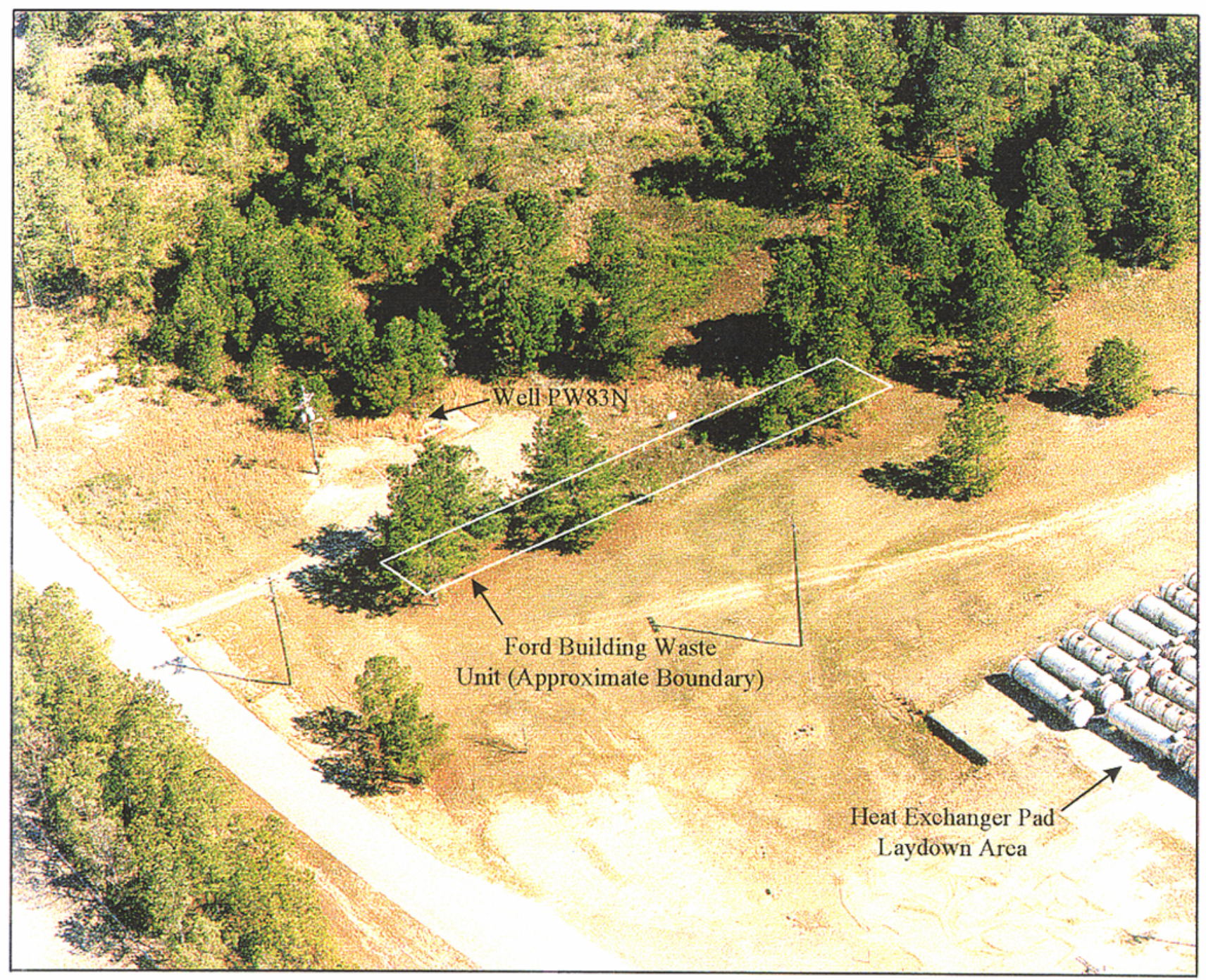

Figure 2. Oblique Aerial Photograph of the FBWU Area (April 1996)

Photograph was taken prior to the 1997 time-critical removal action; the unit is currently grass-covered with two mature pine trees remaining near the northwest corner of the unit (lower left side of the unit on the photograph). 


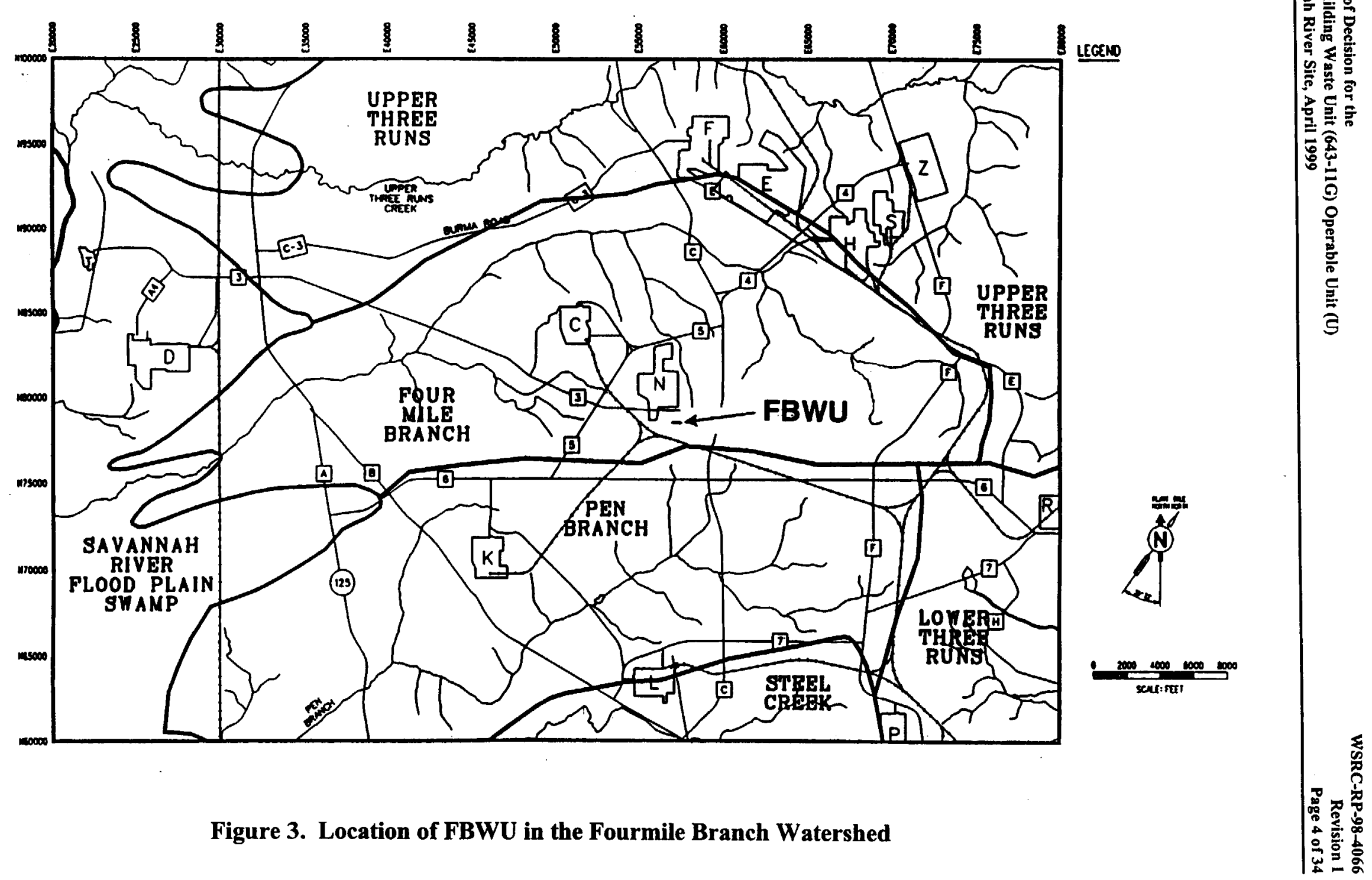




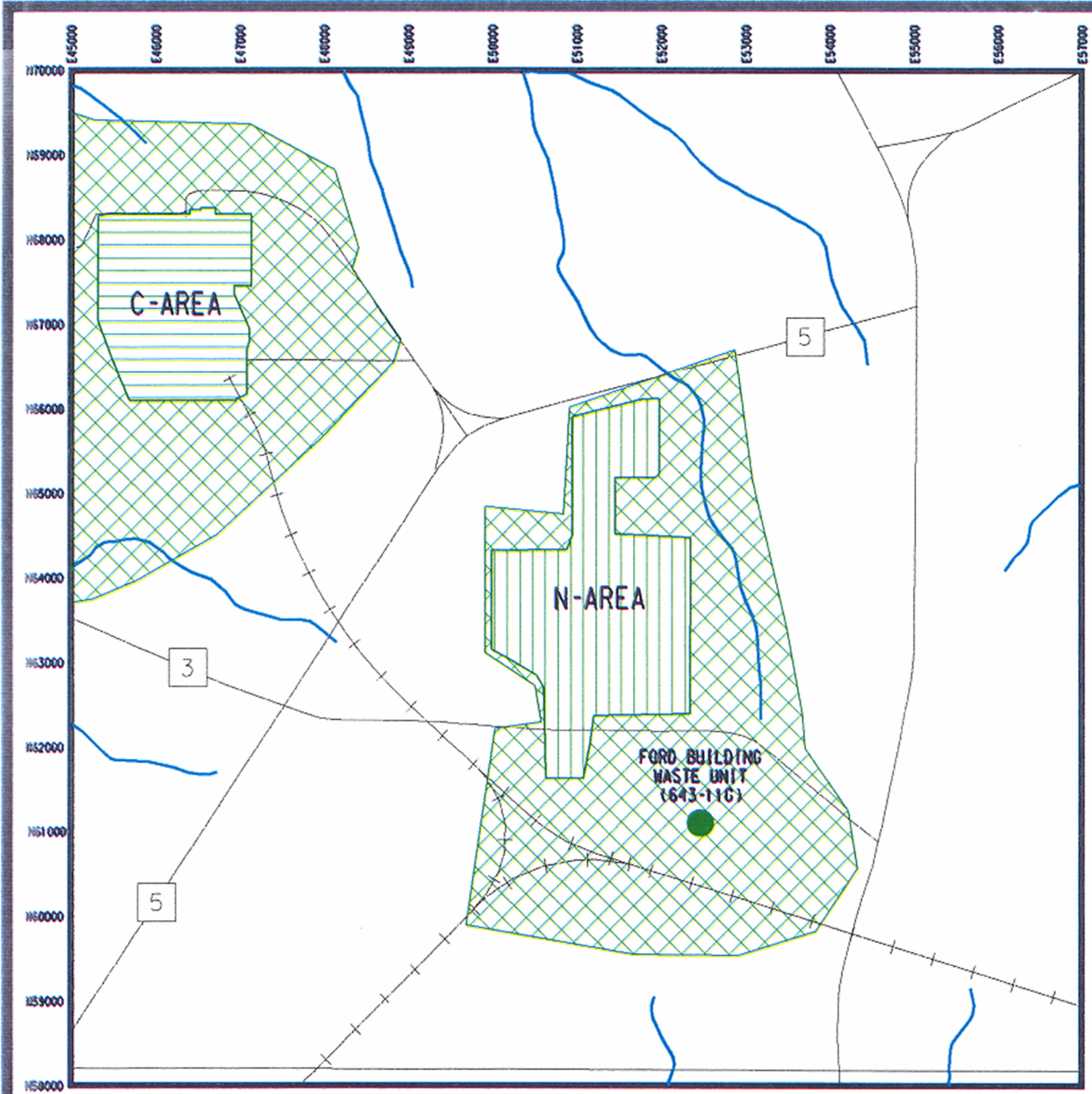

LEGEND

\begin{tabular}{|l}
\hline HEAVY INOUSTRIAL \\
(NUCLEAR)
\end{tabular}

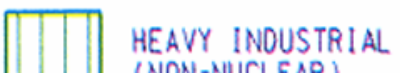

(NON-NUCLEAR)

CURRENT INDUSTRIAL
WITH BUFFER
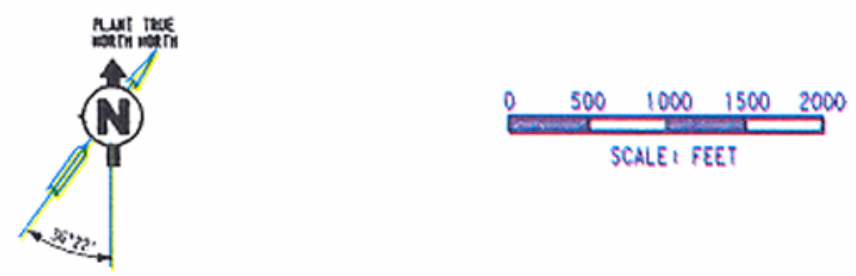

FORO BUILOING

WASTE UNIT $(643-116)$ 


\section{SITE HISTORY AND ENFORCEMENT ACTIVITIES}

\section{Operable Unit History}

Operations with regulated radioactive equipment probably occurred at the FBWU (WSRC, 1998a). The nearby Ford Building was used for the reconfiguration and repair of reactor heat exchangers and other process equipment that had been decontaminated prior to receipt at the facility. There are no records of waste disposal for the FBWU. However, in the past, objects identified on the surface of the waste unit included shoe covers, step-off pads, coveralls, and rubber gloves. These are typical wastes from work performed in radiological controlled areas. In addition, a sign typically used to designate a radiologically controlled area marked the site. This sign, personal protective clothing, and contamination control equipment indicate that regulated work was performed at this location. All surface debris was removed from the unit in an undocumented removal sometime prior to 1992.

Cesium-137 was produced at SRS in tremendous quantities and is a ubiquitous SRS contaminant with a relatively long half-life (about 30 years). It is reasonable to conclude that the radiological work performed at this location resulted in releases of cesium-137 to the soil.

Low levels of radioactivity were detected at the FBWU in 1988 while grounds maintenance work was being performed. A subsequent radiation survey, conducted in 1990, also detected low levels of radioactivity ( 1 millirem per hour). As a result of these findings, the area was posted as a Soil Contamination Area (SCA) to protect site workers from inadvertent exposure. Additionally, a larger area was designated as an Underground Radioactive Materials Area (URMA) to indicate the possibility of buried material. However, subsequent Ground Penetrating Radar survey results, soil sampling results and a time-critical removal action demonstrated that there was no buried waste at the unit.

Based on pre-Work Plan analytical data, cesium-137 was detected at elevated levels in the surface and subsurface soils (Figure 5). A time-critical removal action was implemented in early 1997 to address these secondary sources of contamination. The time-critical removal action focused on removing secondary sources consisting of surface and subsurface soils that contained levels of cesium-137 above the time-critical removal action cleanup goal of 0.35 $\mathrm{pCi} / \mathrm{g}$. The cleanup goal was set to the unit-specific two times $(2 \mathrm{X})$ average background. 


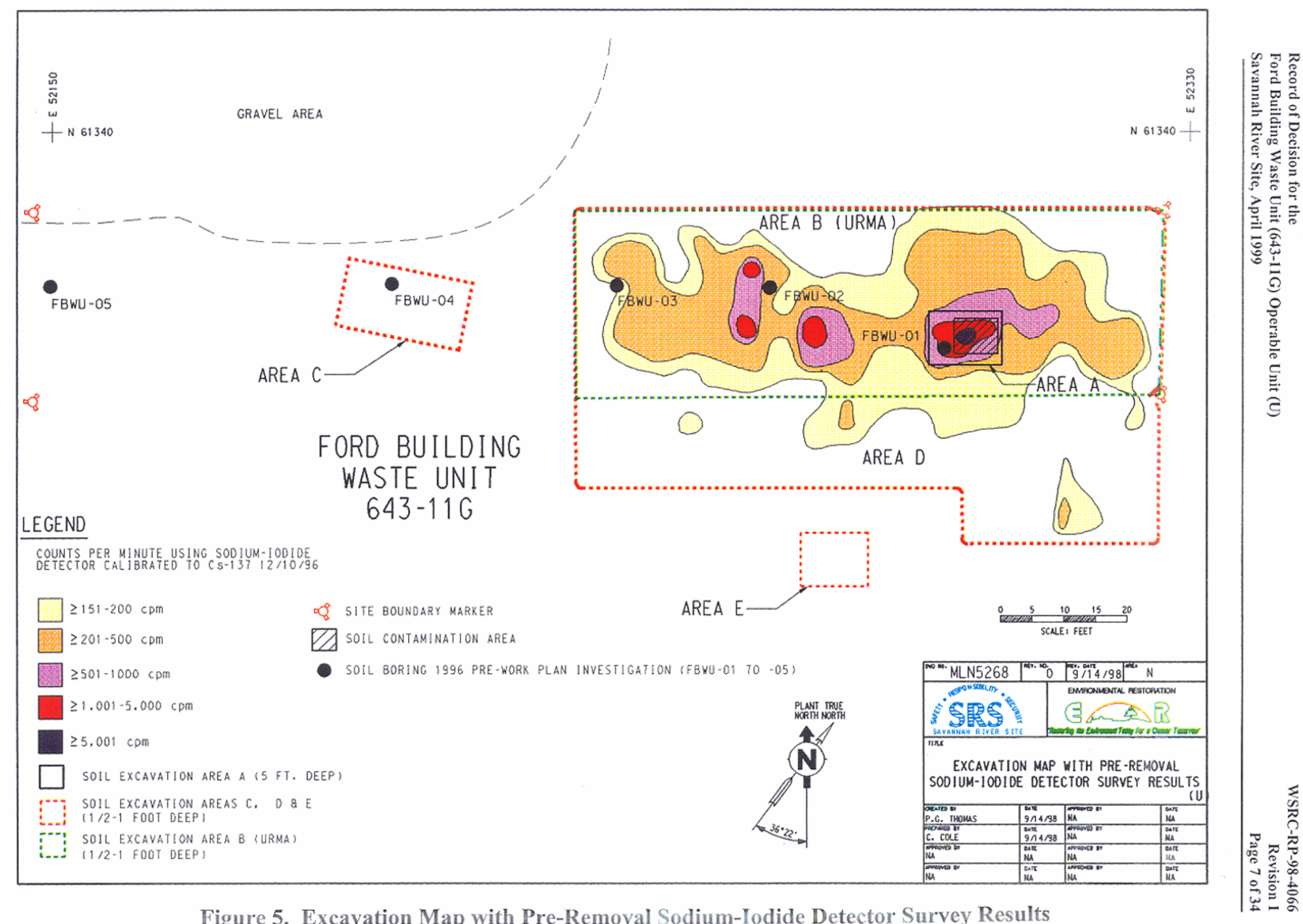

Figure 5. Excavation Map with Pre-Removal Sodium-Iodide Detector Survey Results 
concentration using established protocols at the time. The goal of the time-critical removal action was to remove contaminated soil so that the concentrations and risks associated with cesium-137 in the remaining unit soils would be indistinguishable from those of background. The time-critical removal action was guided by analytical results of soil samples collected during the removal action and field surveys with a sodium-iodide detector calibrated for cesium-137. The following areas, depicted in Figure 5, were removed:

- The SCA and the area around boring FBWU-01 were excavated to a depth of

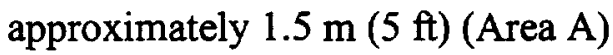

- The URMA was excavated to a depth of approximately $0.3 \mathrm{~m}$ (1 ft) (Area B)

- An area measuring approximately $3 \times 6 \mathrm{~m}(10 \times 20 \mathrm{ft})$ west of the URMA around the site of soil boring FBWU-04 was excavated to a depth of approximately $0.15 \mathrm{~m}(0.5 \mathrm{ft})$ (Area C)

- An area of soil at the south perimeter of the URMA measuring $7.5 \times 27 \mathrm{~m}$ $(25 \times 90 \mathrm{ft})$ was excavated to a depth of 0.15 to $0.3 \mathrm{~m}(0.5$ to $1 \mathrm{ft})$ (Area D)

- An area of soil south of the URMA measuring $2.4 \times 3.0 \mathrm{~m}(8 \times 10 \mathrm{ft})$ was excavated to a depth of 0.15 to $0.3 \mathrm{~m}(0.5$ to $1 \mathrm{ft}$ ) (Area $\mathrm{E}$ )

A total of $96.3 \mathrm{~m}^{3}\left(126 \mathrm{yd}^{3}\right)$ of soil was removed. The waste was placed in skid pans and dispositioned to engineered trenches at the SRS Low Level Radioactive Waste Disposal Facility in E Area. The SRS radiological control organization removed the SCA postings and associated barricades after the time-critical removal action.

\section{SRS Compliance History}

Waste materials handled at SRS are regulated and managed under RCRA, a comprehensive law requiring responsible management of hazardous waste. Certain SRS activities have required federal operating or post-closure permits under RCRA. SRS received a hazardous 
waste permit from the South Carolina Department of Health and Environmental Control (SCDHEC); the permit was most recently renewed on September 5, 1995. Part V of the permit mandates that SRS establish and implement an RFI program to fulfill the requirements specified in Section 3004(u) of the federal permit.

On December 21, 1989, SRS was included on the National Priorities List. The inclusion created a need to integrate the established RFI program with CERCLA requirements to provide for a focused environmental program. In accordance with Section 120 of CERCLA, US DOE has negotiated an FFA (FFA, 1993) with U.S. Environmental Protection Agency (US EPA) and SCDHEC to coordinate remedial activities at SRS into one comprehensive strategy to fulfill these dual regulatory requirements.

\section{Operable Unit Compliance History}

As previously stated, the FBWU is listed in the FFA as a RCRA/CERCLA unit requiring further evaluation to determine the actual or potential impact to human health and the environment. Because pre-Work Plan data indicated the need for a time-critical removal action, an RFI/RI Work Plan was not submitted and a Field Start date was omitted. A Removal Site Evaluation Report (WSRC, 1997) was submitted in September 1996, and the time-critical removal action was performed from January 8 to June 2, 1997. Results of the time-critical removal action were presented in the RFI/RI with Baseline Risk Assessment (BRA) (WSRC, 1998a). The RFI/RI/BRA was submitted in accordance with the FFA and the approved implementation schedule, and was approved by US EPA and SCDHEC in June 1998. By agreement between US EPA, SCDHEC, and US DOE, a "No Further Action" Statement of Basis/Proposed Plan was developed without the need for a Corrective Measures Study/Feasibility Study. The Statement of Basis/Proposed Plan was submitted in accordance with the FFA and the approved implementation schedule and was approved by the US EPA and SCDHEC in October 1998.

\section{HIGHLIGHTS OF COMMUNITY PARTICIPATION}

Both RCRA and CERCLA require that the public be given an opportunity to review and comment on the draft permit modification and proposed remedial remedy. Public 
participation requirements are listed in South Carolina Hazardous Waste Management Regulation (SCHWMR) R.61-79.124 and Sections 113 and 117 of CERCLA. These requirements include establishment of an Administrative Record File that documents the investigation and selection of the remedial remedy for addressing the FBWU soils and groundwater. The Administrative Record File must be established at or near the facility at issue. The SRS Public Involvement Plan (US DOE, 1994) is designed to facilitate public involvement in the decision-making process for permitting, closure, and the selection of a remedial solution. The SRS Public Involvement Plan addresses the requirements of RCRA, CERCLA, and the National Environmental Policy Act. SCHWMR R.61-79.124 and Section 117(a) of CERCLA, as amended, require the advertisement of the draft permit modification and notice of any proposed remedial action and provide the public an opportunity to participate in the selection of the remedial action. The Statement of Basis/Proposed Plan for the Ford Building Waste Unit (643-11G) (WSRC, 1998b), which is part of the Administrative Record File, highlights key aspects of the investigation and identifies the preferred action for addressing the FBWU.

The FFA Administrative Record File, which contains the information pertaining to the selection of the response action, is available at the US EPA office and at the following locations:

U. S. Department of Energy

Public Reading Room

Gregg-Graniteville Library

University of South Carolina-Aiken

171 University Parkway

Aiken, South Carolina 29801

(803) 641-3465
Asa H. Gordon Library

Savannah State University

Tompkins Road

Savannah, Georgia 31404

(912) 356-2183 
Thomas Cooper Library

Government Documents Department

University of South Carolina

Columbia, South Carolina 29208

(803) $777-4866$
Reese Library

Augusta State University

2500 Walton Way

Augusta, Georgia 30910

(706) $737-1744$

The public was notified of the public comment period through the SRS Environmental Bulletin, a newsletter sent to approximately 3,500 citizens in South Carolina and Georgia, through notices in the Aiken Standard, the Allendale Citizen Leader, the Augusta Chronicle, the Barnwell People-Sentinel, and The State newspapers. The public comment period was also announced on local radio stations.

The 45-day public comment period for the Statement of Basis/Proposed Plan and the draft RCRA permit modification began on November 15,1998 , and ended on January 1,1999 . No comments were received during the public comment period.

\section{SCOPE AND ROLE OF OPERABLE UNIT WITHIN THE SITE STRATEGY}

The overall strategy for addressing the FBWU was to (1) characterize the waste unit by delineating the nature and extent of contamination and identifying the media of concern (perform the RFI/RI); (2) perform a time-critical removal action; (3) perform a BRA to evaluate media of concern, constituents of concern (COCs), exposure pathways, and characterize potential risks; and (4) evaluate and perform a final action to remediate, as needed, the identified media of concern.

The FBWU is a source control and groundwater operable unit in the Fourmile Branch watershed. There are no ditches, drainage areas, or surface waters associated with the unit. An unnamed tributary of Fourmile Branch is located approximately $396 \mathrm{~m}(1,300 \mathrm{ft})$ to the north-northeast of the FBWU.

The SRS has recently concluded a surface and subsurface soil investigation at the FBWU. The unit was initially evaluated with another waste site, but based upon preliminary 
characterization results, SCDHEC and US EPA concurred with US DOE's proposal to separate the operable unit into two operable units (i.e., the FBWU and the Fire Department Hose Training Facility). SCDHEC and US EPA also agreed that the investigation at the FBWU adequately characterized contamination within that unit and along potential migration pathways. This Record of Decision (ROD) will propose a final remedial action for the FBWU operable unit.

\section{SITE CHARACTERISTICS}

\section{Media Assessment}

The soil sampling activities conducted at the FBWU and background locations (Figures 6 and 7) provided data on the types and extent of constituents present. These data were supplemented by soil gas surveys conducted in 1986 and 1992 and field surveys with a sodium-iodide detector conducted in 1997 . The primary source of contamination at the FBWU was miscellaneous radiological materials (removed prior to 1992). Secondary sources of contamination were surface and subsurface soils (removed by the time-critical removal action in 1997).

A conceptual site model was prepared which shows the potential human health and ecological receptors and exposure pathways to assist in determining what samples were needed during characterization. This conceptual site model is shown in Figure 8.

Pre-Work Plan sampling in 1996 consisted of five borings in the FBWU (FBWU-01 through -05) (Figure 7) and five background borings (FBFDBG-01 through -05) (Figure 6). Five depth intervals were sampled in each of these borings ( 0 to $0.3,0.3$ to $1.2,1.2$ to 2.1 , 2.1 to 3.1 , and 3.1 to either 4.0 or $4.3 \mathrm{~m}$ [ 0 to 1,1 to 4,4 to 7,7 to 10 , and 10 to either 13 or $14 \mathrm{ft}$ ] below land surface [bls]). Each sample was analyzed for a comprehensive suite of constituents including Target Analyte List inorganics with cyanide, Target Compound List (TCL) volatile organic compounds with tentatively identified compounds (TICs), TCL semivolatile organic compounds with TICs, pesticides, polychlorinated biphenyls, and radionuclides. Gamma speciation was performed on all pre-Work Plan samples; alpha and 
Record of Decision for the

Ford Building Waste Unit (643-11G) Operable Unit (U)

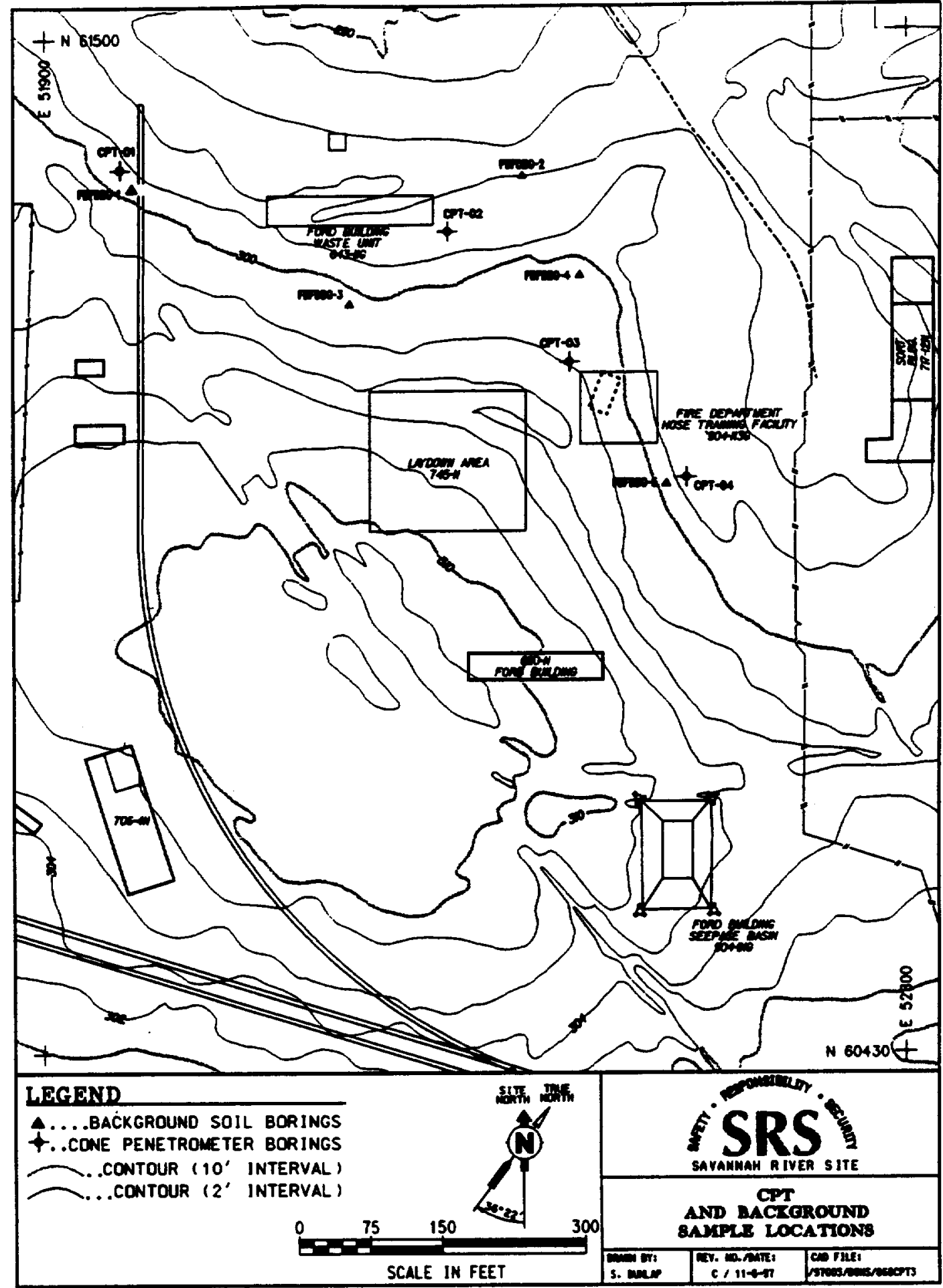

Figure 6. Location of Background Soil Borings 


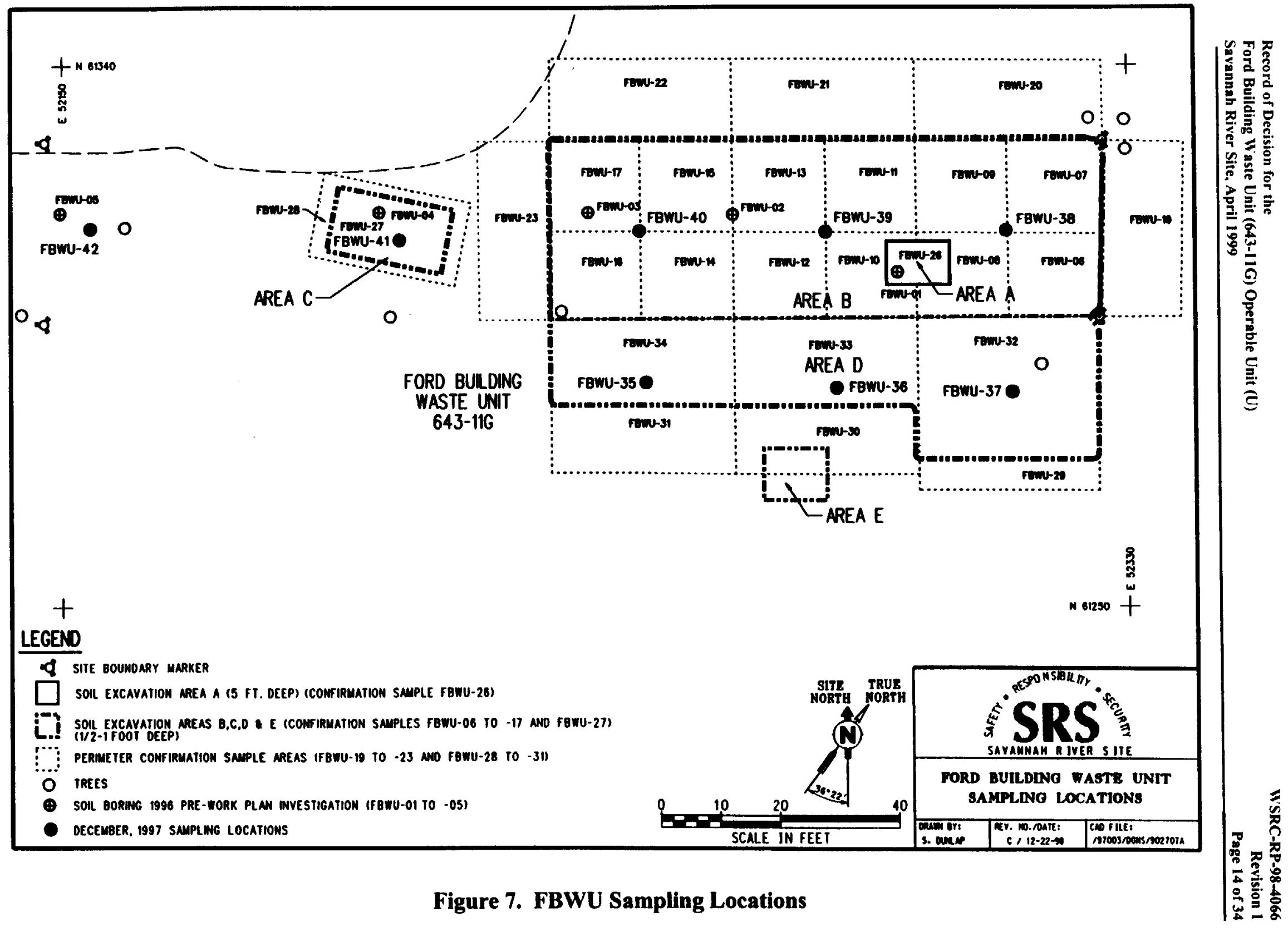




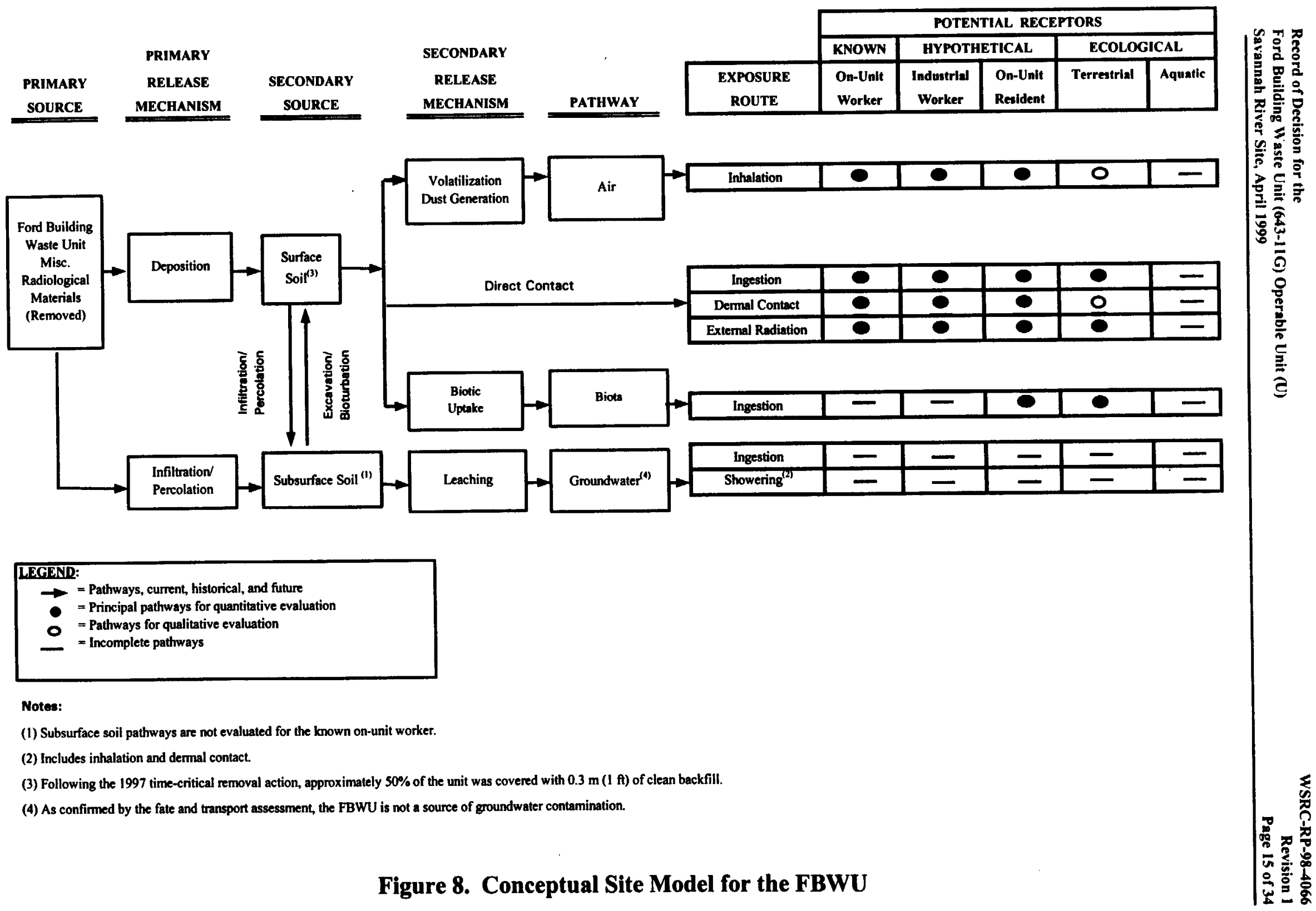


beta speciation was performed on selected samples. Alpha speciation included americium-241, radium-226, uranium-234, uranium-235, uranium-238, plutonium-238, plutonium-239, plutonium-240, plutonium-242, plutonium-244, thorium-228, thorium-230, and thorium-232; beta speciation included iodine-129, carbon-14, technetium-99, strontium-90, promethium-147, and radium-228. The sampling program was designed to establish the presence or absence of hazardous and/or radiological substances at the FBWU. The maximum detected concentration for each constituent was compared to $2 \mathrm{X}$ the average background concentration to identify unit-specific constituents (USCs). Based on the analytical data, cesium-137 was targeted for remediation. Using protocols established at the time, a $2 \mathrm{X}$ average background concentration of $0.35 \mathrm{pCi} / \mathrm{g}$ for cesium-137 was used as the time-critical removal action cleanup goal (WSRC, 1998a).

Composite confirmatory soil samples were collected during the time-critical removal action to guide soil removal. Samples were collected from the floors of the excavations as well as from unexcavated areas around the lip of each excavation (perimeter samples) (Figure 7). These samples were composite samples of five individual soil aliquots collected in each sampling area. The composite soil samples were split into two sets. One set was screened onsite by WSRC for cesium-137 to facilitate decision making during the time-critical removal action. If the cesium-137 concentration in any sample exceeded the time-critical removal action cleanup goal, additional soil was removed from that area and the area was sampled and screened again. If the onsite screening indicated the cesium-137 concentration was below the time-critical removal action cleanup goal, the excavation stopped and the remaining split sample set was sent to an US EPA-approved laboratory for analysis and verification (WSRC, 1998a). The time-critical removal action was considered complete when the cesium-137 concentrations, as determined by the US EPA-approved laboratory did not exceed the time-critical removal action cleanup goal of $0.35 \mathrm{pCi} / \mathrm{g}$. Figure 7 shows the locations of 26 of the 29 composite confirmatory sample locations. The other three samples were collected from Area D and were removed by subsequent excavation (Figure 7). Contaminated soil and exhumed tree roots were the only materials removed under the time-critical removal action. The waste was placed in skid pans and dispositioned to engineered trenches at the SRS Low Level Radioactive Waste Disposal Facility in E Area 
(WSRC, 1998a). The SRS radiological control organization removed the SCA postings and associated barricades within the unit and declared the unit unrestricted.

After the time-critical removal action, 16 discrete, location-specific surface soil ( 0 to $0.3 \mathrm{~m}$ [0 to $1 \mathrm{ft}$ ] bls) and subsurface soil ( 0.3 to $1.2 \mathrm{~m}$ [1 to $4 \mathrm{ft}$ ] bls) samples were collected in December 1997 and analyzed for cesium-137 (borings FBWU-35 to -42). Cesium-137 was detected in six of the eight surface soil samples. The detected concentrations ranged from a minimum of $0.07 \mathrm{pCi} / \mathrm{g}$ (location FBWU-35) to a maximum of $0.22 \mathrm{pCi} / \mathrm{g}$ (location FBWU-37) with an average surface soil concentration of $0.095 \mathrm{pCi} / \mathrm{g}$. No point sources of cesium-137 contamination were apparent. Cesium-137 was below method detection limits in all subsurface samples.

Due to the small areal extent of the unit $\left(<464 \mathrm{~m}^{2}\left[<5,000 \mathrm{ft}^{2}\right]\right)$, the surface and near surface location of the contamination $(<3 \mathrm{~m}[<10 \mathrm{ft}] \mathrm{bls})$, the distance from contamination to the water table ( 13.7 to $16.8 \mathrm{~m}$ [ 45 to $55 \mathrm{ft}$ ] bls), the high percentage of clays in the top $9.1 \mathrm{~m}$ (30 ft) of soil, and the affinity for cesium-137 to bind to clays, the FBWU was not considered a likely source of groundwater contamination. Consequently, the investigation of groundwater was not part of the pre-Work Plan characterization. However, a fate and transport analyses were performed as part of the RFI/RI/BRA evaluation.

Fate and transport analyses conducted for USCs identified at the FBWU revealed selenium and potassium-40 exceed the unit-specific soil screening levels. The predicted maximum concentration in groundwater for both exceeded the corresponding groundwater Applicable, or Relevant and Appropriate Requirements (ARARs), consequently, selenium and potassium-40 were retained as preliminary contaminant migration constituents of concern (CM COCs). Both preliminary CM COCs were eliminated in the uncertainty analysis, and no final CM COCs were retained at the FBWU.

\section{SUMMARY OF SITE RISKS}

As a component of the remedial investigation process, a BRA was prepared for the FBWU. The BRA consists of human health and ecological risk assessments. Summary information for the human health and ecological risk assessments follows. 
The environmental data used in the risk assessments, including the sample intervals, sample locations, and sample identification numbers, can be found in RCRA Facility Investigation/Remedial Investigation Report with Baseline Risk Assessment for the Ford Building Waste Unit (643-11G) (WSRC, 1998a).

\section{Human Health Risk Assessment}

The human health risk assessment characterizes both the potential risk from exposure to carcinogenic substances and adverse health effects from noncarcinogens to human receptors exposed to unit-related constituents under current and future land use conditions (Figures 9 and 10). The risks listed in this section were derived from the BRA (WSRC, 1998a) which used the data obtained from the RFI/RI characterization.

The BRA designates the constituents of potential concern (COPCs) based on a conservative screen against background concentrations and the relative potential of the chemicals to cause toxic or carcinogenic effects. Constituents soil concentrations that produce a threshold risk less than the risk-based concentration levels are screened from further analysis. Threshold risk is defined as constituent concentrations that exceed either a cancer risk of $1 \mathrm{E} 10^{-6}$ or a hazard quotient (HQ) of 0.1. At the FBWU, identified COPCs included cesium-137 and beryllium.

Three land use assumptions were made to describe the human receptors that may be exposed to these constituents. Potential receptors are expected to differ for the current and future land use scenarios. The possible receptor under the current land use scenario includes the known on-unit worker. The possible receptors under the future land use scenario include the on-unit industrial worker and the on-unit resident (adult and child).

Carcinogenic risks are estimated as the incremental probability of an individual developing cancer over a lifetime as a result of pathway-specific exposure to cancer-causing contaminants. The risk to an individual resulting from exposure to non-radioactive chemical carcinogens is expressed as the increased probability of cancer occurring over the course of a 70-year lifetime. Cancer risks are related to the US EPA target risk range of one in ten thousand $\left(1 \mathrm{E} 10^{-4}\right)$ to one in one million $\left(1 \mathrm{E} 10^{-6}\right)$ for incremental cancer risk at National Priorities List sites. Risk levels greater than $1 \mathrm{E} 10^{-6}$ require a risk management decision 

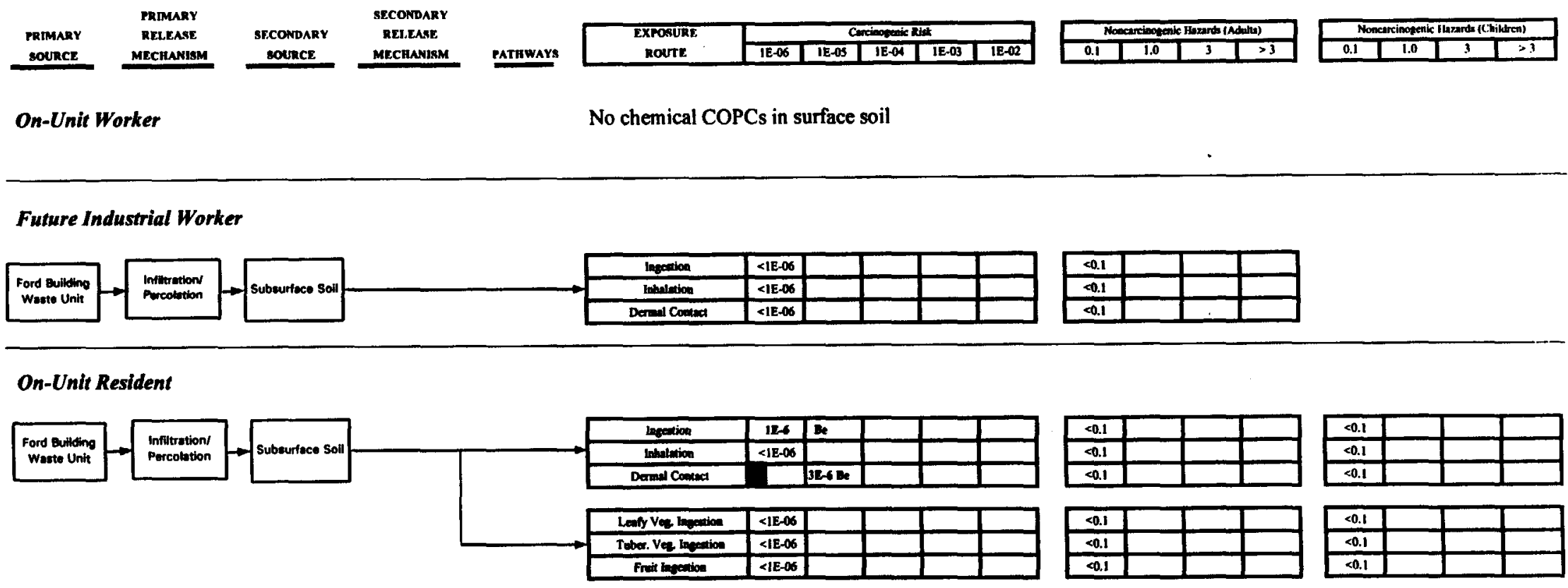

Figure 9. Summary of Chemical Risks and Hazards Across Pathways 

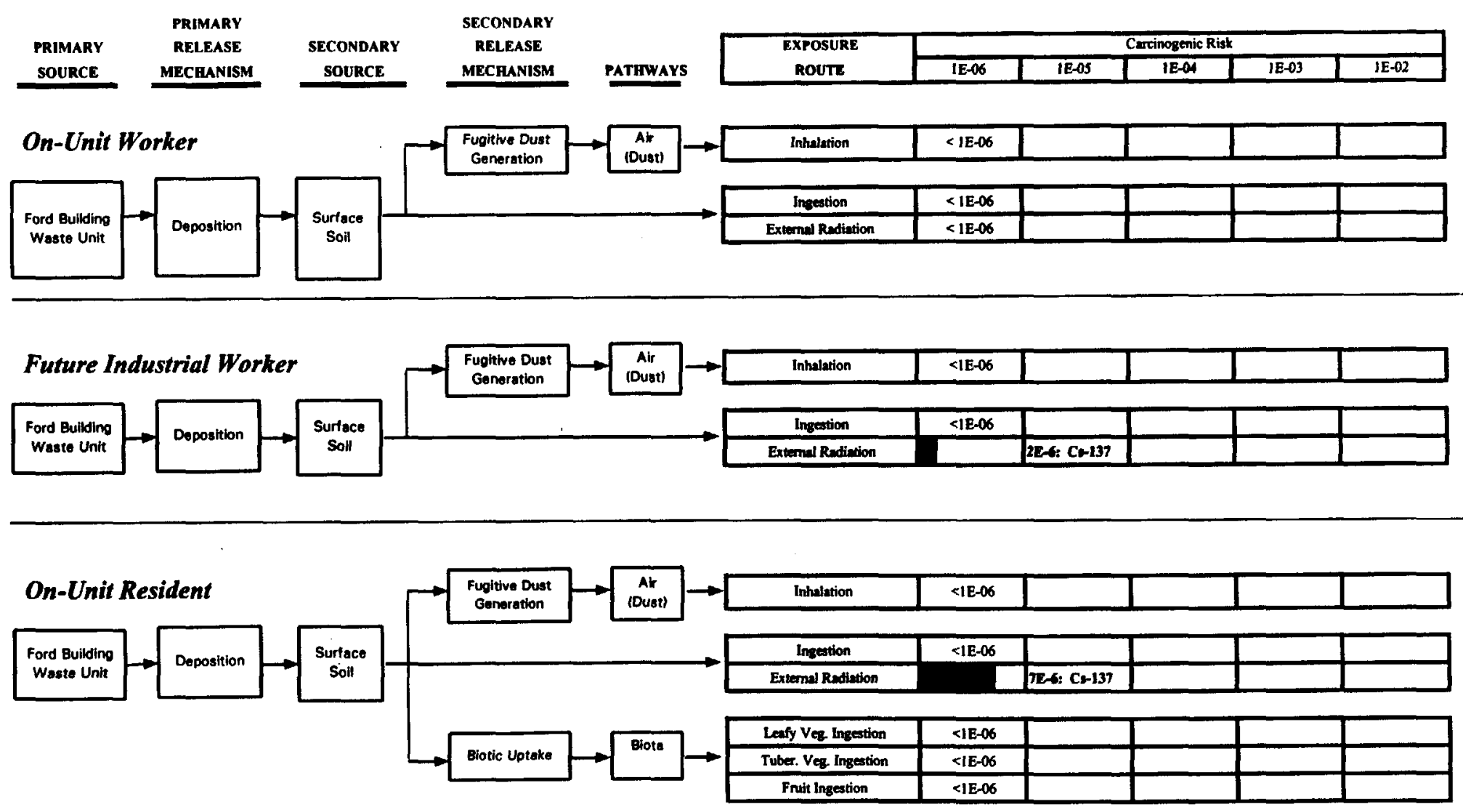

Figure 10. Summary of Radiological Risks Across Pathways 
where specific actions to reduce risk may be considered, while cancer risk levels below $1 \times 10^{-6}$ are considered to be insignificant.

Non-carcinogenic effects are also evaluated to identify a level at which there may be concern for potential non-carcinogenic health effects. The HQ, which is the ratio of the exposure dose to the reference dose, is calculated for each contaminant. HQs are summed for each exposure pathway to determine the specific hazard index (HI) for each exposure scenario. If the $\mathrm{HI}$ exceeds unity (1.0), the potential exists that adverse health effects might occur.

The following sections discuss the excess lifetime cancer risk (ELCR) and combined HI values that were determined in the BRA for current workers, future industrial workers, and the future residential child/adult. A summary of the human health risks for the various land use scenarios is provided in the following sections, Figures 9 and 10, and Tables 1 through 3 .

\section{Current Worker}

The current worker was evaluated for the 0 to $0.3 \mathrm{~m} \mathrm{(} 0$ to $1 \mathrm{ft}$ ) bls soil interval only. There are no chemical COPCs in the surface soil at the FBWU. Therefore, chemical carcinogenic risks and chemical noncarcinogenic hazards were not calculated for the known on-unit worker (Figure 9). Under the current land use scenario, radiological risks from cesium-137 are characterized for ingestion, external radiation exposure, and inhalation exposure to surface soil (Figure 10). The total medium risk (TMR) for the known on-unit worker based on the summation of exposure routes is $6 \mathrm{E} 10^{-9}$. All of the estimated risks are less than $1 \mathrm{E}$ $10^{-6}$, indicating that radiological risk is insignificant at the unit under current conditions.

\section{Future Industrial Worker}

The industrial worker was evaluated for the 0 to $0.3 \mathrm{~m}(0$ to $1 \mathrm{ft})$ bls and 0 to $1.2 \mathrm{~m}$ ( 0 to $4 \mathrm{ft})$ bls soil intervals. Carcinogenic risks and noncarcinogenic hazards associated with beryllium were calculated for the hypothetical on-unit industrial worker from exposure to redistributed subsurface soil and air (Figure 9). Radiological risks associated with cesium-137 were calculated for the hypothetical on-unit industrial worker exposed to cesium-137 in surface soils and air (Figure 10). 
Table 1. Risk Characterization Summary: Current Land Use Scenario - Surface Soil

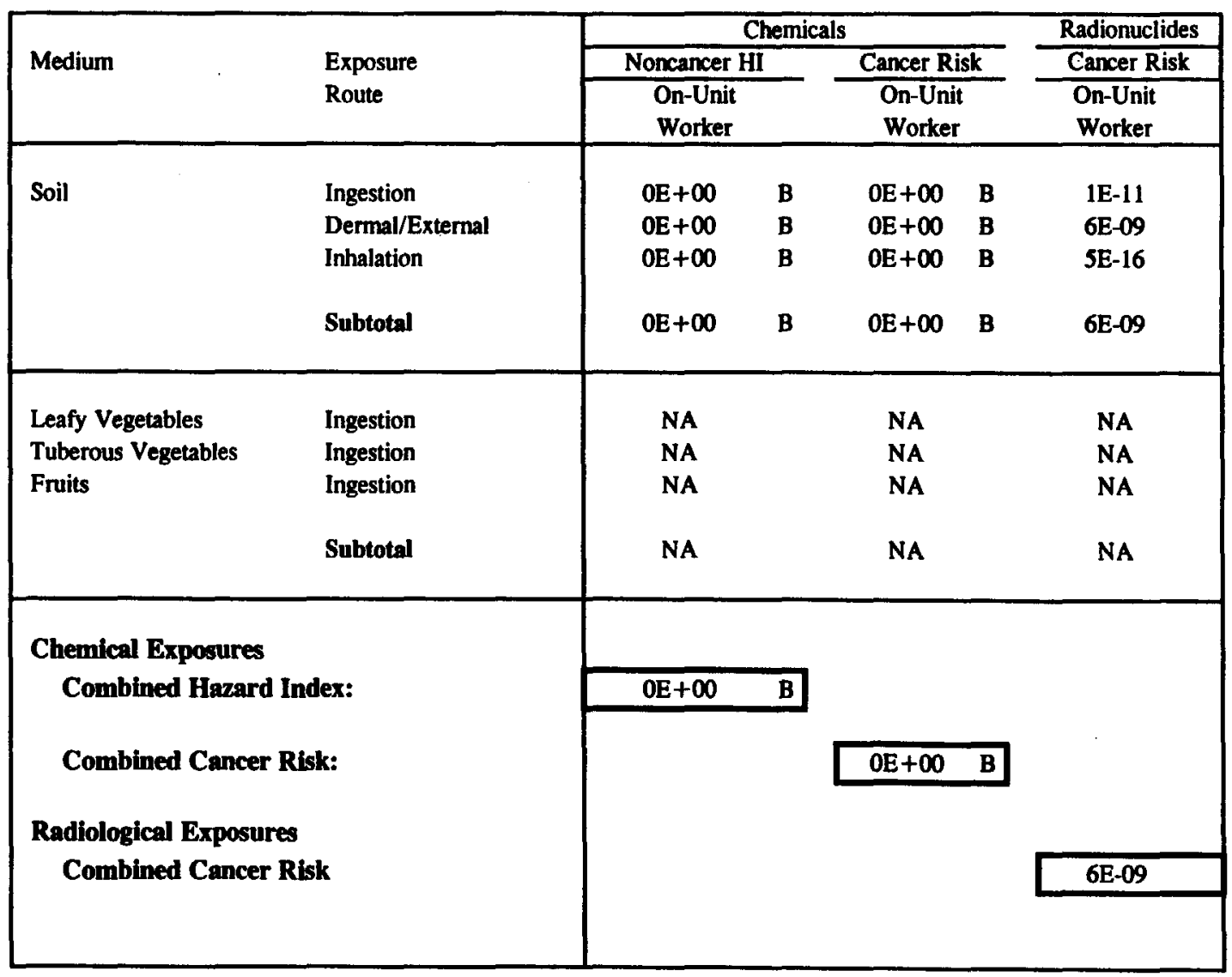

NA - pathway not evaluated

$0 \mathrm{E}+00$ - pathway evaluated but no risks could be calculated due to lack of US EPA-approved toxicity values

B - $\mathrm{HI} \leq 1$ or ELCR $\leq 10^{-6}$

E - HI $>1$ or ELCR $>10^{-6}$ 
Table 2. Risk Characterization Summary: Future Land Use Scenarios - Surface Soil

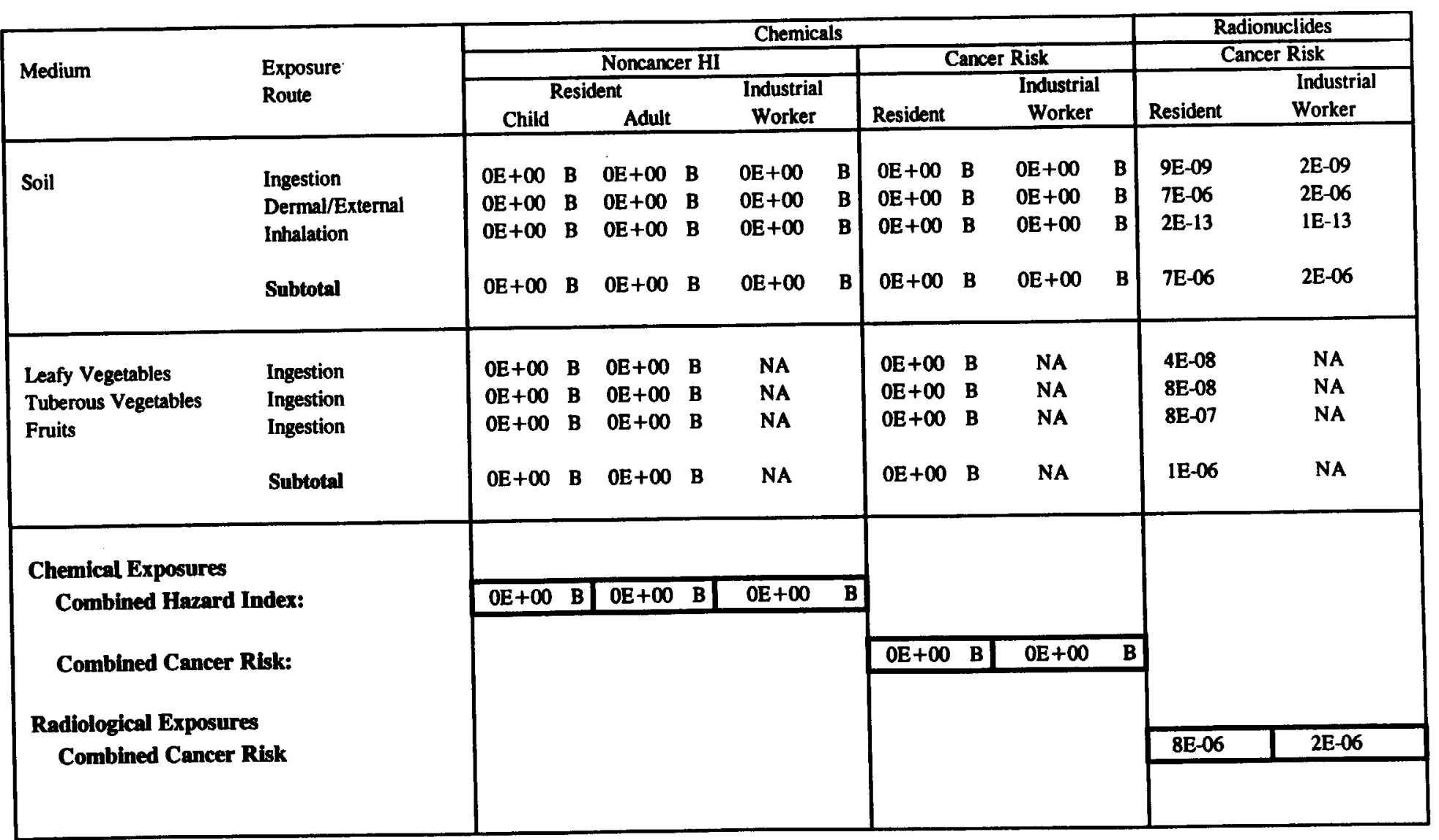

NA - pathway not evaluated

$0 E+00$ - pathway evaluated but no risks could be calculated due to lack of US EPA-approved toxicity values

B $-\mathrm{HI} \leq 1$ or ELCR $\leq 10^{-6}$

E $-\mathrm{HI}>1$ or ELCR $>10^{-6}$ 
Table 3. Risk Characterization Summary: Future Land Use Scenarios - Subsurface Soil

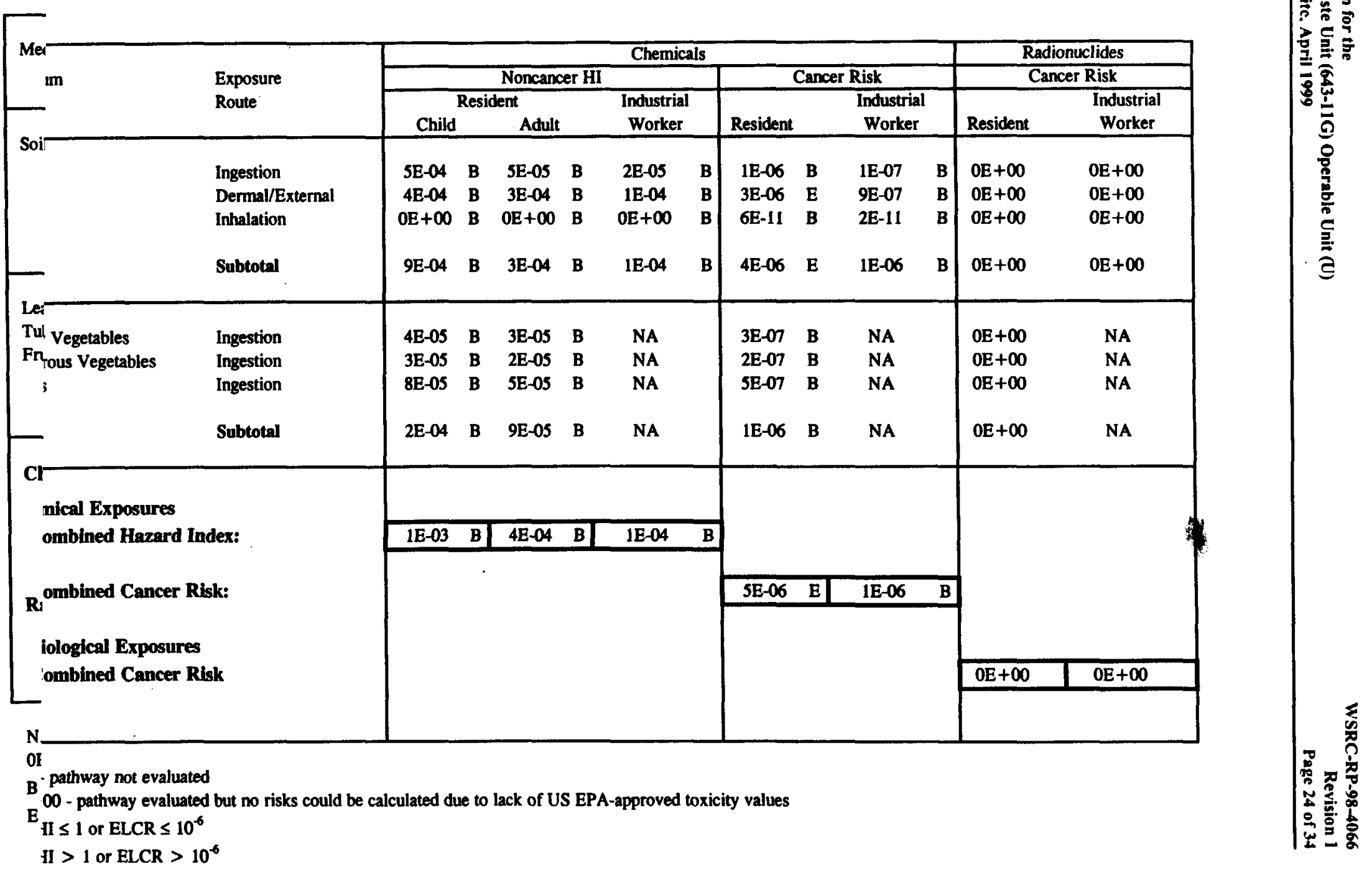


Carcinogenic Risk: For subsurface soil, the TMR for the hypothetical on-unit industrial worker based on the summation of exposure routes is $1 \mathrm{E} 10^{-6}$. All of the estimated risks by pathway are less than $1 \mathrm{E} 10^{-6}$ (ingestion of soil $=1 \mathrm{E} 10^{-7}$, dermal contact with soil $=9 \mathrm{E} 10^{-7}$, and inhalation of particulates from soil $=2 \mathrm{E} 10^{-11}$ ). Under future conditions, chemical risk for the industrial worker is insignificant at the unit.

Noncarcinogenic Hazard: For subsurface soil, the total cumulative hazard index (TCHI) for the hypothetical on-unit industrial worker based on the summation of exposure routes is $1 \mathrm{E}$ $10^{-4}$. The HIs for all pathways are well below 1 . All of the estimated hazards by pathway are well below 1. Under future conditions, chemical hazard for the industrial worker is insignificant at the unit.

Radiological Risk: For surface soil, the TMR for the hypothetical on-unit industrial worker based on the summation of exposure routes is $2 \mathrm{E} 10^{-6}$. Radiological risks were estimated for three soil exposure routes: ingestion of soil $\left(2 \mathrm{E} 10^{-9}\right)$; direct, external radiation exposure from soil $\left(2 \mathrm{E} 10^{-6}\right)$; inhalation of particulates from soil $\left(1 \mathrm{E} 10^{-13}\right)$. Cesium-137 is a preliminary $\mathrm{COC}$ for the external radiation exposure pathway.

\section{Residential Adult/Child}

The residential scenario was evaluated at the 0 to $0.3 \mathrm{~m}(0$ to $1 \mathrm{ft}) \mathrm{bls}$ and the 0 to $1.2 \mathrm{~m}$ $(0$ to $4 \mathrm{ft}) \mathrm{bls}$ soil intervals. Under the future land use scenario, carcinogenic risks and noncarcinogenic hazards associated with beryllium were calculated for the hypothetical on-unit resident (adult and child) from exposure to redistributed subsurface soils, air, and homegrown produce (Figure 9). Radiological risks associated with cesium-137 were calculated for the hypothetical on-unit resident from exposure to surface soils, air, and homegrown produce (Figure 10).

Carcinogenic Risk: For subsurface soil, the total cumulative risk (TCR) for the hypothetical on-unit resident based on the summation of exposure routes and media is $5 \mathrm{E} 10^{-6}$ (soil TMR $=4 \mathrm{E} 10^{-6}$, produce TMR $=1 \mathrm{E} 10^{-6}$ ). Estimated risks equal or exceed $1 \mathrm{E} 10^{-6}$ for both soil and produce pathways. Chemical risks were estimated for three soil exposure routes: ingestion of soil $\left(1 \mathrm{E} 10^{-6}\right)$, dermal contact with soil $\left(3 \mathrm{E} 10^{-6}\right)$, and inhalation of particulates from soil 
$\left(6 \mathrm{E} 10^{-11}\right)$. Chemical risks were estimated for three produce exposure routes: ingestion of leafy vegetables $\left(3 \mathrm{E} 10^{-7}\right)$, ingestion of tuberous vegetables $\left(2 \mathrm{E} 10^{-7}\right)$, and ingestion of fruits $\left(5 \mathrm{E} 10^{-7}\right)$. Beryllium is a preliminary $\mathrm{COC}$ for the dermal contact and ingestion pathways.

Noncarcinogenic Hazard: Based on the summation of exposure routes and media, the TCHIs for the hypothetical on-unit resident child and adult are $1 \mathrm{E} 10^{-3}$ and $4 \mathrm{E} 10^{-4}$, respectively. The HIs for all pathways are well below 1 , indicating that chemical hazard for the hypothetical on-unit resident is insignificant.

Radiological Risk: For surface soil, the TCR for the hypothetical on-unit resident based on the summation of exposure routes and media is $8 \mathrm{E} 10^{-6}$ (soil TMR $=7 \mathrm{E} 10^{-6}$, produce $\mathrm{TMR}=$ IE $10^{-6}$ ). Radiological risks were estimated for three soil exposure routes: ingestion of soil $\left(9 \mathrm{E} 10^{-9}\right)$; direct, external radiation exposure from soil $\left(7 \mathrm{E} 10^{-6}\right)$; inhalation of particulates from soil $\left(2 \mathrm{E} 10^{-13}\right)$. Radiological risks were estimated for three produce exposure routes: ingestion of leafy vegetables $\left(4 \mathrm{E} 10^{-8}\right)$, ingestion of tuberous vegetables $\left(8 \mathrm{E} 10^{-8}\right)$, and ingestion of fruits $\left(8 \mathrm{E} 10^{-7}\right)$. Cesium-137 is a carcinogenic preliminary COC for the external radiation pathway.

\section{Ecological Risk Assessment}

The ecological BRA for the FBWU evaluated the likelihood of harmful effects to ecological receptors from exposure to contaminants in soil. Ecological receptors serve as assessment endpoints for the risk to plant and animal populations and ecosystems at FBWU.

COPCs are those constituents whose maximum measured concentrations exceeded a toxicity screening value for ecological receptors and $2 \mathrm{X}$ the background mean concentration. No ecological COPCs were identified from among constituents detected at FBWU. Therefore, all exposure pathways are incomplete and the calculation of ecological HQs for current and future exposure of ecological receptors was not required. Consequently, no preliminary COCs were carried forward into the uncertainty analysis and no ecological final COCs were retained. 


\section{Uncertainty}

Preliminary CM COCs identified by the fate and transport analyses and preliminary COCs identified during the risk assessment are evaluated through an uncertainty analysis to determine final COCs. Remedial goal options (RGOs), which become the basis of and the focus for remediation are developed for the list of final COCs.

Fate and transport analyses identified selenium and potassium-40 as preliminary CM COCs. The human health risk assessment identified no preliminary COCs for surface soil under the current land use. Under future industrial land use, cesium-137 was identified as a preliminary $\mathrm{COC}$ for surface soil. Under future residential land use, cesium-137 was identified as a preliminary $\mathrm{COC}$ for surface soil, and beryllium was identified as a preliminary $\mathrm{COC}$ for subsurface soil.

Following the uncertainty analysis, no constituents were retained as final COCs and no RGOs were developed. Key uncertainties for each preliminary $\mathrm{COC}$ are summarized below.

Potassium- 40 was not retained as a final $\mathrm{CM} \mathrm{COC} \mathrm{for} \mathrm{the} \mathrm{following} \mathrm{reasons:}$

- At the FBWU, potassium -40 concentrations range from $0.83 \mathrm{pCi} / \mathrm{g}$ to $3.51 \mathrm{pCi} / \mathrm{g}$. The observed range in background values is virtually identical, $0.76 \mathrm{pCi} / \mathrm{g}$ to $3.5 \mathrm{pCi} / \mathrm{g}$. There does not appear to be a difference between the observed unit and background values and, using present protocols, both unit and background data sets fail the background screen.

- Potassium-40 is a naturally occurring radionuclide present in soils at the SRS. There is no process history of potassium-40 use associated with FBWU and no reason to postulate that it would be associated with the regulated activities that are suspected to have occurred there.

- Potassium-40 was detected in all of the unit samples analyzed. The values that exceed

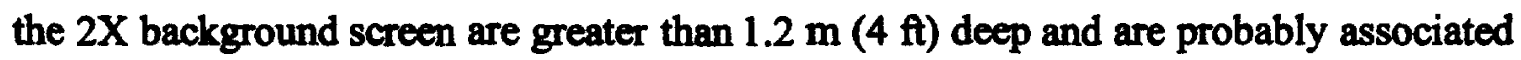
with natural soil profile development. They are not near the surface where the primary source for this unit was located. 
Selenium was not retained as a final CM COC for the following reasons:

- At the FBWU, selenium concentrations range from $1.5 \mathrm{mg} / \mathrm{kg}$ to $3.4 \mathrm{mg} / \mathrm{kg}$. The observed range in background values is similar, $0.416 \mathrm{mg} / \mathrm{kg}$ to $2.9 \mathrm{mg} / \mathrm{kg}$. The unit and background values are similar and, using present protocols, both data sets fail the background screen.

- The laboratory results for selenium are highly questionable. The laboratory method used to identify selenium (inductively coupled plasma) often results in false positives from spectral interference when elevated levels of iron are present in the sample. Review of the unit data found that in all cases where selenium values exceed the background levels, elevated iron concentrations are present in the same sample. The selenium values are therefore viewed as false positives.

- Selenium is a naturally occurring metal. There is no process history of selenium use associated with FBWU and no reason to postulate that it would be associated with the regulated activities that are suspected to have occurred there.

- Selenium was detected in only 5 of 20 samples. The detections are at depth, not near the surface where the primary source for this unit was located. The associated high iron values are probably associated with natural soil profile development.

Beryllium was not retained as a final COC for the following reasons:

- Within the subsurface soils, beryllium concentrations range from $0.09 \mathrm{mg} / \mathrm{kg}$ to $0.21 \mathrm{mg} / \mathrm{kg}$. The observed range in background values is comparable, $0.04 \mathrm{mg} / \mathrm{kg}$ to $0.20 \mathrm{mg} / \mathrm{kg}$. The $2 \mathrm{X}$ average background screening value is $0.15 \mathrm{mg} / \mathrm{kg}$ and the $\mathrm{RBC}$ screening value is also $0.15 \mathrm{mg} / \mathrm{kg}$. The observed unit and background values are indistinguishable, and using present protocols, both unit and background data sets fail the background and RBC screens.

- Beryllium is a naturally occurring metal present in soils at the SRS. There is no process history of beryllium use associated with FBWU, and no reason to postulate that it would be associated with the regulated activities that are suspected to have occurred there. 
- Beryllium is a preliminary COC in subsurface soils at the FBWU for the hypothetical future resident scenario only. The cancer risk associated with this preliminary COC is $4 \mathrm{E}$ $10^{-6}$. Background risk associated with beryllium for the future resident yields a similar value $\left(2 \mathrm{E} 10^{-6}\right)$.

Cesium-137 was not retained as a final COC for the following reasons:

- Only 1 of the 8 surface soil samples from the discrete, post-removal sampling event in December 1997 slightly exceeded the $2 X$ average background value for cesium- 137 (i.e., $0.22 \mathrm{pCi} / \mathrm{g}$ unit vs. $0.19 \mathrm{pCi} / \mathrm{g}$ background). Cesium-137 was not detected in subsurface soils.

- The single cesium-137 value that exceeded $2 \mathrm{X}$ background is located on the perimeter of the waste unit and represents backfill from the Central Shops Borrow Pits.

- Cesium-137 background values for surface soil at the Central Shops Burning Rubble Pits, which are adjacent to the Borrow Pit, ranged from $0.101-0.338 \mathrm{pCi} / \mathrm{g}$. The maximum unit value of $0.22 \mathrm{pCi} / \mathrm{g}$ for cesium-137 is within this range.

- Cesium-137 background values from 16 waste sites at SRS were reviewed. As reported in the Preliminary Background Soils Study Report (US DOE, 1996), the 2X average background value for cesium-137 in surface soils is $0.213 \mathrm{pCi} / \mathrm{g}$ with a maximum background value of $0.57 \mathrm{pCi} / \mathrm{g}$. The $90^{\text {th }}$ percentile for the SRS background surface soils is $0.258 \mathrm{pCi} / \mathrm{g}$ for cesium-137. Thus, 1 out of 10 background samples would be expected to be greater than $0.258 \mathrm{pCi} / \mathrm{g}$. The maximum FBWU unit value of $0.22 \mathrm{pCi} / \mathrm{g}$ out of 8 samples is consistent with the observed background.

- A statistical review of the unit dataset from the 8 discrete post-removal samples and the background dataset indicates that the mean concentrations of cesium-137 are not statistically different (i.e., mean background concentration is $0.094 \mathrm{pCi} / \mathrm{g}$ and mean unit concentration is $0.099 \mathrm{pCi} / \mathrm{g}$ ).

- The risk from the FBWU and the unit background are similar. Both the FBWU unit risk and the unit background risk for the Industrial Worker is $2 \mathrm{E} 10^{-6}$ for external exposure to 
surface soil. Residential risk for external exposure to unit surface soil is $7 \mathrm{E} 10^{-6}$ and $5 \mathrm{E}$ $10^{-6}$ for exposure to unit background surface soil.

Because no final COCs were identified, no RGOs were developed for the FBWU.

\section{CONCLUSIONS}

Fate and transport analyses identified two preliminary CM COCs (potassium-40 and selenium). No human health preliminary COCs were identified under current land use assumptions. Preliminary COCs were identified for the hypothetical industrial worker (cesium-137) and hypothetical on-unit resident (cesium-137 and beryllium). Due to the elimination of both preliminary CM COCs and both human health preliminary COCs through the uncertainty analysis process, no final COCs were retained. Because no final CM COCs, ecological final COCs, or human health final COCs were identified, any residual soil contamination at the unit does not pose a future risk to groundwater, a current or future risk to ecological receptors, or a current or future risk to human health.

\section{Site-Specific Considerations}

Site-specific considerations, based on the conclusions of the BRA and RFI/RI, which suggest no potential for significant risk include:

1) All surface debris was removed from the unit sometime prior to 1992, and no primary sources of contamination remain.

2) The concentrations of constituents in the soil after the time-critical removal action are indistinguishable from the background data.

3) Fate and transport analyses indicate that the unit does not represent a current or future risk to groundwater.

4) The BRA did not identify any final COCs after the uncertainty analysis; therefore, any residual soil contamination at the unit does not pose a current or future risk to human health. 


\section{Remedial Action Objectives}

Remedial action objectives (RAOs) specify USCs, media of concern, potential exposure pathways, and remediation goals. Remediation goals are developed based upon ARARs or RBCs. After the uncertainty analysis, the BRA determined that there are no unit-specific contaminants. Therefore, there are no RAOs. "No Further Action" will be protective of human health and the environment.

\section{Description of "No Further Action" Decision}

According to the US EPA guidance document Guidance on Preparing Superfund Decision Documents (US EPA, 1989), if there is no current or potential threat to human health or the environment and no action is warranted, the CERCLA Section 121 requirements are not triggered. This means that there is no need to evaluate other alternatives or the "No Further Action" remedy against the nine criteria specified under CERCLA.

Under "No Further Action", no treatment will be performed, no institutional controls or engineering controls will be implemented, and no cost will be associated with the remedy. Because no remedial action is being chosen in this ROD, the requirements of CERCLA Section 121 are not triggered and an ARARs analysis is not required.

Based on the RFI/RI/BRA, the FBWU poses no significant risk to human health and the environment. Therefore, "No Further Action" has been selected as the remedy that satisfies the CERCLA criteria. "No Further Action" is the final action for the FBWU operable unit. This solution is meant to be permanent and effective in both the short and long term and is applicable to all media evaluated (soil, groundwater, etc.). The "No Further Action" decision is the least cost option with no capital, operating, or monitoring costs, and is protective of human health and the environment.

This proposal is consistent with US EPA guidance and is an effective use of risk management principles. The Statement of Basis/Proposed Plan provided for involvement with the community through a document review process and a public comment period. 
The selected remedy is protective of human health and the environment and complies with federal and state requirements that are legally applicable or relevant and appropriate to the remedial action.

\section{EXPLANATION OF SIGNIFICANT CHANGES}

The Statement of Basis/Proposed Plan and draft permit modification provide for involvement with the community through a document review process and a public comment period. No comments were received during the public comment period; therefore, no changes were made based on public comments.

\section{RESPONSIVENESS SUMMARY}

No comments on the Statement of Basis/Proposed Plan were received from the public during the public comment period. Therefore, a Responsiveness Summary was not prepared. 


\section{REFERENCES}

FFA, 1993. Federal Facility Agreement for the Savannah River Site, Administrative Docket No. 89-05-FF, Effective Date: August.

US DOE, 1994. Public Involvement, A Plan for Savannah River Site. United States Department of Energy, Savannah River Operations Office, Aiken South Carolina.

US DOE, 1996. Preliminary Background Soils Study Report. Rev. 0. United States Department of Energy, Savannah River Operations Office, Environmental Restoration Division, November.

US EPA, 1989. Guidance on Preparing Superfund Decision Documents. Office of Solid Waste and Emergency Response - OSWER Directive 9355.3-02, Washington, DC, July WSRC, 1997. Removal Site Evaluation Report for Soil Removal at the Ford Building Waste Unit (643-11N) (U), WSRC-RP-96-850, Rev. 1, Westinghouse Savannah River Company, Aiken, South Carolina, February.

WSRC, 1998a. RCRA Facility Investigation/Remedial Investigation with Baseline Risk Assessment for the Ford Building Waste Unit (643-11G), WSRC-RP-97-190, Rev. 1, Westinghouse Savannah River Company, Aiken, South Carolina, May.

WSRC, 1998b. Statement of Basis/Proposed Plan for the Ford Building Waste Unit (643-11G) Operable Unit (U), WSRC-RP-98-4065, Rev. 1, Westinghouse Savannah River Company, Aiken, South Carolina, October. 
